\title{
Public-Private Partnership in the Implementation of National Environmental Projects
}

Ernesto Spremberg

Case Manager Agent at Sellbytel, Airbnb Project, Germany

Volodymyr Tykhenko

$\mathrm{PhD}$, Assistant, Department of Management, Sumy State University, Ukraine

Liliana Lopa

PhD Student, Sumy State University, Ukraine

\begin{abstract}
Increasing the risks of climate change, natural and man-made disasters, as well as the manifestation of their negative environmental and economic consequences at the national and supranational levels, envisages the introduction of the concept of sustainable development and the United Nations Millennium Development Goals. The implementation of large-scale environmental projects in the form of joint implementation projects, public-private partnerships, distribution agreements, etc. is possible only if an effective system of managing these projects is formed at the national and supranational levels. The object of the study is a public-private partnership. The subject of the study is the increase of the effectiveness of national environmental projects implementation.
\end{abstract}

Keywords: public-private partnership, national environmental projects, agreement on the division of products, shale gas.

\section{JEL Classification: Q01.}

(C) The Authors, 2017. This article is published with open access at ARMG Publishing.

\section{Introduction}

Today the public-private partnership is an effective method of managing environmental projects in the framework of the state and municipal environmental management system because of the existence of market externalities. Public-private partnership is an equal and mutually beneficial cooperation between the state, territorial communities (represented by the relevant state authorities or local self-government) and private investors in the implementation of projects aimed at solving important socio-economic problems connected with the territory [8]. The growing interest of the state in the development of public-private partnership is due to its advantages in attracting resources (primarily financial and investment). The appearance of a private investor ensures more efficient use of financial resources at the stage of project implementation and is capable to increase the profitability of the facilities in the course of their further operation.

The works of Bamberger M., Blake M. et al., Inderst G. et al., Osita C. et al., etc. convincingly testify the cooperation between business and the state in the format of public-private partnership and can be considered as an effective tool for developing reserves of energy resources, preserving water resources, introducing energy-saving technologies, ensuring environmental protection and implementing green projects in general in conditions of limited budget resources through the built-in ability to activate investment potential [18].

At the same time, one of the main management problems in the Practical Guide on Good Governance in the sphere of public-private partnerships of the United Nations Economic Commission in Europe is the fact that the public-private partnership projects should necessarily contribute to sustainable development and environmental protection.

In accordance with Part 1 of Article 5 of the Law of Ukraine "On Public-Private Partnership", among the forms of public-private partnership can be distinguished concessions, joint activities, product sharing, other contracts.

Such a form of public-private partnership as a production sharing in extractive industry is relatively unexplored and applied in national practice. According to Part 1 of Article 4 of the Law of Ukraine "On 
Production Sharing Contracts" (Production Sharing Law), the production sharing agreement is an agreement whereby one side of Ukraine (the state) instructs the other party (the investor) for a certain period of time search, exploration and mining of mineral resources in a certain section (sites) of subsoil and maintenance of work related to the agreement, and the investor undertakes to perform the assigned works at his own expense and at his own risk with subsequent compensation of costs and receipt of payment in the form of a part of profitable output [26].

We offer to pay attention to production sharing contracts with such a transnational company as Chevron (the winner of the competition for signing a production sharing contract on Oleska area).

The authors suggest a comparative study of characteristics of extraction and marketing of non-traditional hydrocarbon deposits in the United States and European countries (including Ukraine) from the perspective of the development of this extractive industry and possibility to use shale gas for production sharing contract implementation within the framework of public-private projects partnership considering the environmental and economic consequences (Table 1).

Table 1. Ecological and economic analysis of production and marketing of shale gas in the United States and European countries

\begin{tabular}{|c|c|c|c|}
\hline Comparison criteria & United States & European countries & Commentary \\
\hline Geological conditions & $\begin{array}{ll}- & \text { Relatively shallow } \\
\text { boreholes; } \\
\text { - } \\
\text { Deposits of shale gas are } \\
\text { at insignificant depth; } \\
\text { - } \quad \text { Strata of gas bearing } \\
\text { rock have a simple } \\
\text { structure. }\end{array}$ & $\begin{array}{ll}- & \text { Greater depth of } \\
\text { occurrence of shale gas; } \\
-\quad \text { Higher pressure; } \\
-\quad \text { Complex tectonic structure. }\end{array}$ & $\begin{array}{l}\text { European countries have more } \\
\text { complex gas production conditions, } \\
\text { which require additional } \\
\text { investment in the development of } \\
\text { deposits and increase the cost of } 1 \\
\mathrm{~m}^{3} \text { of gas and create an additional } \\
\text { burden on the environment. }\end{array}$ \\
\hline $\begin{array}{l}\text { Hydrological } \\
\text { conditions }\end{array}$ & $\begin{array}{l}\text { High level of water supply for } \\
\text { hydraulic fracturing. }\end{array}$ & $\begin{array}{l}\text { Limited reserves of renewable } \\
\text { water resources (the Czech } \\
\text { Republic, Germany, Poland). }\end{array}$ & $\begin{array}{l}\text { The increase in the cost of water } \\
\text { resources will lead to an increase in } \\
\text { the cost of gas and the destruction } \\
\text { of aquatic ecosystems. }\end{array}$ \\
\hline Land resources & $\begin{array}{l}\text { Free access to land for wells' } \\
\text { construction. }\end{array}$ & $\begin{array}{l}\text { The ownership of land belongs } \\
\text { to the state. }\end{array}$ & $\begin{array}{l}\text { Difficult access to land plots with } \\
\text { promising deposits in Europe, } \\
\text { unlike the US, where landowners } \\
\text { receive royalties from the } \\
\text { placement of wells. }\end{array}$ \\
\hline $\begin{array}{l}\text { Demographic } \\
\text { conditions }\end{array}$ & Low population density. & $\begin{array}{l}\text { One of the highest population } \\
\text { density. }\end{array}$ & $\begin{array}{l}\text { Gas deposits are located in urban } \\
\text { areas in European countries, which } \\
\text { makes it difficult to extract. }\end{array}$ \\
\hline $\begin{array}{l}\text { Technological } \\
\text { conditions }\end{array}$ & 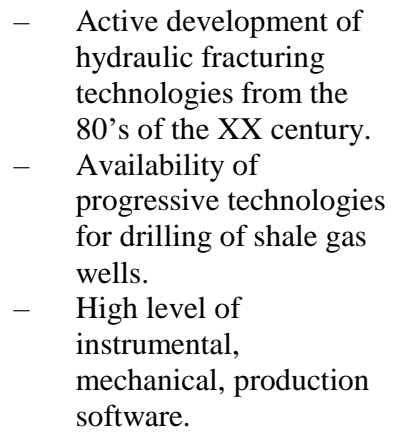 & $\begin{array}{l}\text { The need for the development } \\
\text { and dissemination of } \\
\text { technologies for the extraction } \\
\text { of shale gas, the development of } \\
\text { all types of supply of this sector. }\end{array}$ & $\begin{array}{l}\text { The rise in price of gas due to the } \\
\text { increase in the amount of initial } \\
\text { investment in the development of } \\
\text { gas fields, the construction of } \\
\text { appropriate wells, the acquisition of } \\
\text { necessary technologies. }\end{array}$ \\
\hline Staff potential & Significant staffing potential. & $\begin{array}{l}\text { The lack of a sufficient number } \\
\text { of highly qualified specialists. }\end{array}$ & $\begin{array}{l}\text { The need for investment in staff } \\
\text { training. }\end{array}$ \\
\hline Infrastructure & $\begin{array}{l}\text { The existing extensive } \\
\text { infrastructure is sufficient for } \\
\text { the US needs, the prospective } \\
\text { construction of gas terminals } \\
\text { makes its import possible. }\end{array}$ & $\begin{array}{l}\text { A significant need for the } \\
\text { development of infrastructure } \\
\text { elements to ensure the } \\
\text { production and transportation of } \\
\text { gas. }\end{array}$ & $\begin{array}{l}\text { The creation of an appropriate } \\
\text { infrastructure requires significant } \\
\text { investment. }\end{array}$ \\
\hline
\end{tabular}

Source: compiled by authors.

The consideration of the environmental aspects of production sharing contract as a form of publicprivate partnership focuses on the comparison of environmental consequences and threats of shale gas production on the one hand and economic feasibility of such extraction in the context of ensuring 
energy independence, technological capabilities, profitability (productivity) of exploited deposits and return on investment.

\section{Methodology}

Insisting on the need for strategic evaluation of public-private partnership projects in terms of environmental and economic efficiency and feasibility, we propose a detailed methodology for evaluating such projects, which includes two types of criterial analysis (PESTLE analysis and SWOT analysis), which are complementary and allow us to disclose key terms of the project, its impact on the environment and the role in promoting environmental initiatives in particular and the principles of sustainable development.

Its practical approbation will be carried out using PESTLE analysis and SWOT analysis as complementary types of analysis with the help of the example of hydrocarbons sharing contract between the company Chevron Ukraine BV and JSC Nadra Oleska, which were concluded between the state of Ukraine and Chevron for the production of shale gas at Oleska site (Lviv and Ivano-Frankivsk regions). The application of PESTLE analysis is justified in order to determine the appropriateness of using the production sharing contract as a form of a public-private enterprise, since it makes it possible to identify not only political, economic, social or technological factors of the external environment, but unlike short methods (PEST analysis (sometimes STEP)), take into account legal and environmental factors (legal and environmental) (Osita et al., 24). Based on the PESTLE analysis, the results of which are summarized in Table 2, we will comment in detail political, social, technological and legal factors; exhaustive explanations of environmental and economic factors will be provided in the course of SWOT analysis.

Table 2. The matrix of PESTLE-analysis of macro-environment factors affecting the implementation of public-private partnership projects in the form of a production sharing contract

\begin{tabular}{|c|c|c|}
\hline Political factors & Economic factors & Social factors \\
\hline \multirow{2}{*}{$\begin{array}{l}\text { - The instability of the political } \\
\text { environment and frequent personnel } \\
\text { changes that affect the policy vectors. }\end{array}$} & \multirow[t]{3}{*}{$\begin{array}{l}\text { - Unjustified structure and level of prices for } \\
\text { shale gas in Ukraine. }\end{array}$} & $\begin{array}{l}\text { - High population density in } \\
\text { the areas of potential production. }\end{array}$ \\
\hline & & \multirow{2}{*}{$\begin{array}{l}\text { - There may be problems with } \\
\text { the loss of housing and settled } \\
\text { places of residence. }\end{array}$} \\
\hline $\begin{array}{l}\text { - The lack of a clear procedure for } \\
\text { granting licenses for gas production by } \\
\text { foreign companies. }\end{array}$ & & \\
\hline $\begin{array}{l}\text { - The opacity of the conclusion of } \\
\text { production sharing contracts, distribution } \\
\text { of profit, land allocation procedures. }\end{array}$ & $\begin{array}{l}\text { - Insignificant savings on energy resources } \\
\text { used. }\end{array}$ & $\begin{array}{l}\text { - The lack of opportunities to } \\
\text { attract local labor for the projects } \\
\text { implementation. }\end{array}$ \\
\hline $\begin{array}{l}\text { The neglection of development } \\
\text { priorities of local self-government bodies } \\
\text { and state interests. }\end{array}$ & $\begin{array}{l}\text { - The lack of legislative mechanisms for } \\
\text { redistribution of revenues from gas sales to } \\
\text { local communities. }\end{array}$ & $\begin{array}{l}\text { - The destruction of local } \\
\text { infrastructure and growth of } \\
\text { social tension. }\end{array}$ \\
\hline $\begin{array}{l}\text { - The need for additional state support } \\
\text { (subsidies) for the development of the } \\
\text { mining industry. }\end{array}$ & $\begin{array}{l}\text { - Interfering with the development of } \\
\text { alternative energy sector and energy saving } \\
\text { technologies, agriculture, tourism due to }\end{array}$ & \\
\hline $\begin{array}{l}\text { - High corruption risks in the } \\
\text { conclusion of production sharing contract } \\
\text { with the involvement of international } \\
\text { investors, the distribution of products, } \\
\text { reimbursement of compensation costs. }\end{array}$ & diversion of resources. & $\begin{array}{l}-\quad \text { Problems with loss of land } \\
\text { ownership in the production area. }\end{array}$ \\
\hline \multirow{2}{*}{$\begin{array}{l}\text { - The absence of the necessary } \\
\text { infrastructure for the production and } \\
\text { marketing of shale gas (well-arranged } \\
\text { areas for wells, pipelines, storage } \\
\text { facilities, transport infrastructure). }\end{array}$} & $\begin{array}{l}\text { - Unsettled order of land allocation and } \\
\text { transfer of ownership of land plots on which it } \\
\text { is planned to build wells. }\end{array}$ & $\begin{array}{l}-\quad \text { The impact on people and } \\
\text { demographic situation. }\end{array}$ \\
\hline & $\begin{array}{l}\text { - The adoption of necessary legislative acts } \\
\text { that consider the interests of specific private } \\
\text { parties as a result of their lobbying. }\end{array}$ & $\begin{array}{l}-\quad \text { Pollution and reduction of } \\
\text { water resources. }\end{array}$ \\
\hline \multirow{2}{*}{$\begin{array}{l}\text { - Inadequate development of hydraulic } \\
\text { fracturing technology, lack of necessary } \\
\text { equipment, skilled labor and software for } \\
\text { fracturing, considering complex } \\
\text { production conditions. }\end{array}$} & $\begin{array}{l}\text { - A systematic violation of environmental } \\
\text { regulations during the conclusion of production } \\
\text { sharing contract. }\end{array}$ & $\begin{array}{l}-\quad \text { Negative impact on the } \\
\text { lithosphere. }\end{array}$ \\
\hline & $\begin{array}{l}\text { The lack of regulatory support for the use } \\
\text { of fracturing technology. }\end{array}$ & $\begin{array}{l}\text { Degradation of land } \\
\text { resources, reduction of the land } \\
\text { fund. }\end{array}$ \\
\hline
\end{tabular}


Table 2 (cont.). The matrix of PESTLE-analysis of macro-environment factors affecting the implementation of public-private partnership projects in the form of a production sharing contract

\begin{tabular}{|l|l|l|}
\hline \multicolumn{1}{|c|}{ Political factors } & \multicolumn{1}{|c|}{ Economic factors } & \multicolumn{1}{|c|}{ Social factors } \\
\hline & \begin{tabular}{l} 
The lack of regulatory support and \\
organizational mechanisms for compensation of \\
losses caused by the environment and \\
\cline { 2 - 3 }
\end{tabular} & $\begin{array}{l}\text { Air pollution and impact on } \\
\text { elimate change. }\end{array}$ \\
\hline $\begin{array}{l}\text { The lack of reliable data on shale gas } \\
\text { reserves in gas-bearing areas. }\end{array}$ & $\begin{array}{l}\text { Other types of threats, in- } \\
\text { cluding negative impact on } \\
\text { biodiversity. }\end{array}$ \\
\hline
\end{tabular}

Source: compiled by authors.

Thus, the compensation costs incurred by the investor (Chevron can be carried out for a long time; while the share of the state will remain minimal, and the well-being will be exhausted [23]. At the same time, environmental and economic factors should be considered with the help of SWOT analysis, which allows not only to conduct an in-depth study, but also to structure them according to the positive and negative potential and actual consequences of production sharing contract for the production of shale gas (Table 3).

Table 3. The matrix of SWOT-analysis of environmental and economic factors for the implementation of production sharing contract for the production of shale gas as a form of public-private enterprise

\begin{tabular}{|c|c|c|c|}
\hline \multicolumn{3}{|c|}{ Positive impact (Strengths) } & \multirow{2}{*}{$\begin{array}{l}\text { Negative impact (Weaknesses) } \\
\text { The state (the state system for the } \\
\text { management of environmental projects, the } \\
\text { municipal system for the management of } \\
\text { environmental projects) }\end{array}$} \\
\hline \multirow{5}{*}{ Economic } & $\begin{array}{l}\text { State (state management system } \\
\text { for environmental projects, } \\
\text { municipal environmental } \\
\text { management system) }\end{array}$ & Private partners & \\
\hline & $\begin{array}{l}\text { Reducing government spending } \\
\text { on the development of gas } \\
\text { production }\end{array}$ & $\begin{array}{l}\text { Access to implementation of } \\
\text { significant projects and of } \\
\text { investments diversification }\end{array}$ & $\begin{array}{l}\text { Absence of a justification for the price of } \\
\text { shale gas in Ukraine and an } \\
\text { incomprehensible procedure for its structure } \\
\text { formation }\end{array}$ \\
\hline & \multirow{3}{*}{$\begin{array}{l}\text { Assistance in the implementation } \\
\text { of infrastructure projects that can } \\
\text { not be performed in the context of } \\
\text { limited budget resources }\end{array}$} & \multirow[t]{3}{*}{$\begin{array}{l}\text { Acquisition of additional } \\
\text { sources of income and } \\
\text { business development }\end{array}$} & $\begin{array}{l}\text { Absence of necessary provision (reserve) for } \\
\text { the compensation of negative influence and } \\
\text { environmental restoration }\end{array}$ \\
\hline & & & Minor savings on energy used \\
\hline & & & $\begin{array}{l}\text { Absence of legislative mechanisms for } \\
\text { redistribution of revenues from gas sales to } \\
\text { local communities }\end{array}$ \\
\hline \multirow{9}{*}{ Ecological } & $\begin{array}{l}\text { Increase in revenues to the state } \\
\text { budget, which positively affects } \\
\text { the growth of the share of } \\
\text { environmental expenditures in its } \\
\text { structure }\end{array}$ & \multirow[t]{8}{*}{$\begin{array}{l}\text { Development of standards } \\
\text { and practices of } \\
\text { environmental activities and } \\
\text { their integration into the } \\
\text { business processes of the } \\
\text { company }\end{array}$} & $\begin{array}{l}\text { Influence on human health due to } \\
\text { environmental pollution by toxic, allergic, } \\
\text { carcinogenic and mutagenic substances }\end{array}$ \\
\hline & \multirow{7}{*}{$\begin{array}{lll}\text { Reducing public } & \text { spending } & \text { on } \\
\text { environmental } & \text { projects } & \text { in } \\
\text { production areas } & & \end{array}$} & & $\begin{array}{l}\text { Pollution of groundwater, soil, rivers and } \\
\text { lakes with heavy metals, radionuclides }\end{array}$ \\
\hline & & & $\begin{array}{l}\text { Reducing the supply of drinking water in the } \\
\text { place of extraction }\end{array}$ \\
\hline & & & $\begin{array}{l}\text { Contamination of soils with fracturing sub- } \\
\text { stances }\end{array}$ \\
\hline & & & Decommissioning of agricultural land \\
\hline & & & $\begin{array}{l}\text { Evaporation of freckled liquids from } \\
\text { sedimentation tanks to air }\end{array}$ \\
\hline & & & $\begin{array}{l}\text { Increasing the air pollution by vehicles and } \\
\text { equipment serving the wells }\end{array}$ \\
\hline & & & $\begin{array}{l}\text { Contamination due to gas flaring, traffic of } \\
\text { servicing vehicles, etc. }\end{array}$ \\
\hline & $\begin{array}{l}\text { Increasing the level of energy } \\
\text { security of the state and } \\
\text { independence from energy import }\end{array}$ & $\begin{array}{l}\text { Possibility of obtaining tax } \\
\text { benefits, a favorable regime } \\
\text { for investment activities, } \\
\text { government guarantees and } \\
\text { access to credit resources }\end{array}$ & $\begin{array}{l}\text { Resistance to the development of alternative } \\
\text { energy sector and energy saving } \\
\text { technologies }\end{array}$ \\
\hline
\end{tabular}


Table 3 (cont.). The matrix of SWOT-analysis of environmental and economic factors for the implementation of production sharing contract for the production of shale gas as a form of public-private enterprise

\begin{tabular}{|c|c|c|c|}
\hline \multicolumn{3}{|c|}{ Positive impact (Strengths) } & Negative impact (Weaknesses) \\
\hline \multirow{6}{*}{ Ecological } & $\begin{array}{l}\text { Stimulation of economic growth } \\
\text { due to the multiplier effect due to } \\
\text { the development of a separate } \\
\text { industry - the production of shale } \\
\text { gas and related industries }\end{array}$ & & Potential losses to agriculture \\
\hline & $\begin{array}{l}\text { Promoting innovative } \\
\text { development and increasing the } \\
\text { competitiveness of the national } \\
\text { economy through the formation } \\
\text { of a favorable investment climate, } \\
\text { reducing corruption and } \\
\text { increasing transparency }\end{array}$ & $\begin{array}{l}\text { Formation of a positive } \\
\text { image through the } \\
\text { implementation of large- } \\
\text { scale national industry } \\
\text { projects, effective } \\
\text { management and use of } \\
\text { resources }\end{array}$ & $\begin{array}{l}\text { Reducing the tourist attractiveness of mining } \\
\text { regions }\end{array}$ \\
\hline & \multirow{4}{*}{$\begin{array}{l}\text { Implementation of economic } \\
\text { principles sustainable } \\
\text { development in the } \\
\text { implementation of projects with } \\
\text { environmental initiatives }\end{array}$} & \multirow{4}{*}{$\begin{array}{l}\text { The use of environmental } \\
\text { initiatives as a practice of } \\
\text { social responsibility } \\
\text { increases the value of } \\
\text { business } \\
\text { Management and loyalty of } \\
\text { stakeholders }\end{array}$} & $\begin{array}{l}\text { Growth of seismic activity and destruction of } \\
\text { landscapes as a result of injection of freckled } \\
\text { fluid in vacuum }\end{array}$ \\
\hline & & & $\begin{array}{l}\text { Influence on nature protection zones and } \\
\text { recreational resources }\end{array}$ \\
\hline & & & High accident rate \\
\hline & & & $\begin{array}{l}\text { Decreased quality of life and deteriorated } \\
\text { living conditions of people }\end{array}$ \\
\hline
\end{tabular}

Source: compiled by authors.

Regarding the strengths and possibilities of using the production sharing contracts as the forms of public-private partnership, it should be noted that, they are fully disclosed and systematized for the participants in public-private partnership in scientific sources.

Concerning the economic weaknesses of production sharing contracts, it is worth noting the following. Due to the lack of confirmed data on economically viable shale gas reserves, complex technological and geological conditions, and also given the survey data of more than 200 experts in oil and gas production, there is a situation where the economic efficiency of shale gas production is reached at a price from 560 USD to 650 USD for thousand $\mathrm{m}^{3}$ [24]. In the context of low environmental significance of the production sharing contract, the availability of mandatory provision (reserve) for compensation of negative influence and environmental restoration as an economic implementation factor, in our opinion, should be an important condition for its completion. The order of formation of such a reserve will be considered further.

\section{Results}

The calculation of compensation involves the use of discount method and consists of the following stages:

Stage 1. The establishment of a list of costs that can be capitalized as an investor's production assets.

Stage 2. The determining the life of assets for the purpose of extracting shale gas.

Stage 3. The rationale for the discount rate, which will determine the value of the reserve in time.

Stage 4. The calculation of the amount of the reserve and the determination of initial investment value of assets.

Stage 5. The calculation of the amount of financial expenses that are capitalized as a part of the reserve on an annual basis [20].

Thus, at the first stage, according to the data obtained from Oleska area, Chevron costs at the exploration stage (compensation costs) amounts to 354,314,487 USD:

$>$ pre-contract stage - 2714487.00 USD;

$>$ geological survey of the site - 350000000 USD; 
costs of the pilot and industrial development stage - 1600000 USD.

On the next stage of determining the life of assets, it should be noted that the average shale gas production in the well is rapidly depleted (79-95\% in the first 36 months). That is, under the most optimistic scenario, we can take the lifetime of such assets at the level of 3 years [17].

The best practice of oil and gas industry operates with the concept of reserves at the level of $20 \%$ of the total cost of investments in the development of deposits, and therefore the amount of the reserve for environmental restoration over three years should be $20 \%$ of investment costs and equal to 70862897 USD (354314487 USD x 20\%).

At the next stage it is necessary to calculate its present value. According to our calculations, the amount of the reserve for environmental impact and restoration in 2015 should be set at 5,688,294 USD, provided that its total amount for 3 years should be 70,862,897 USD. Consequently, upon initial recognition of the reserve, the amount is included in the original cost of investor's assets: 354314487 USD + 56882947 $\mathrm{USD}=411197434.4$ USD.

In the course of approaching the date of extraction completion and the need to restore the environment, the discounting period decreases and the discounted value of reserve increases. This increase will be reflected in the financial expenses of the operator company and will be 56882947 USD $\times 7.6 \%=$ 4323.104 USD, and the reserve as of 31.12 .15 will be 61206051 USD.

Table 4. The calculation of the amount of reserve for environmental impact compensation and recovery by Chevron

\begin{tabular}{|c|c|c|c|c|}
\hline Data & Reserve amount, UAH & Discount rate & $\begin{array}{c}\text { Financial expenses, } \\
\text { UAH }\end{array}$ & $\begin{array}{c}\text { Initial cost of } \\
\text { investments, UAH }\end{array}$ \\
\hline 1 & 2 (2 graph + 4 graph) & 3 & 4 (2 graph x 3 graph) & 5 \\
\hline January 1, 2015 & 56882947,0 & $7.6 \%$ & 4323104,0 & 411197434,4 \\
\hline December 31, 2015 & 61206051,0 & $7.6 \%$ & 4651660,0 & - \\
\hline December 31, 2016 & 65857711,0 & $7.6 \%$ & 5005186,0 & - \\
\hline December 31, 2017 & 70862897,0 & - & - & - \\
\hline
\end{tabular}

In total, considering the approach to the implementation of the project approach with the initiators of the World Bank projects (1,457 banks globally implemented 1,712 projects for the amount of 176.4 bln USD). We will consider in detail the participation of this international financial institution in the implementation of large-scale national environmental projects in Ukraine. In particular, since 1993 the World Bank implemented 84 projects totaling 10,201.79 mln USD in Ukraine (Figure 1).

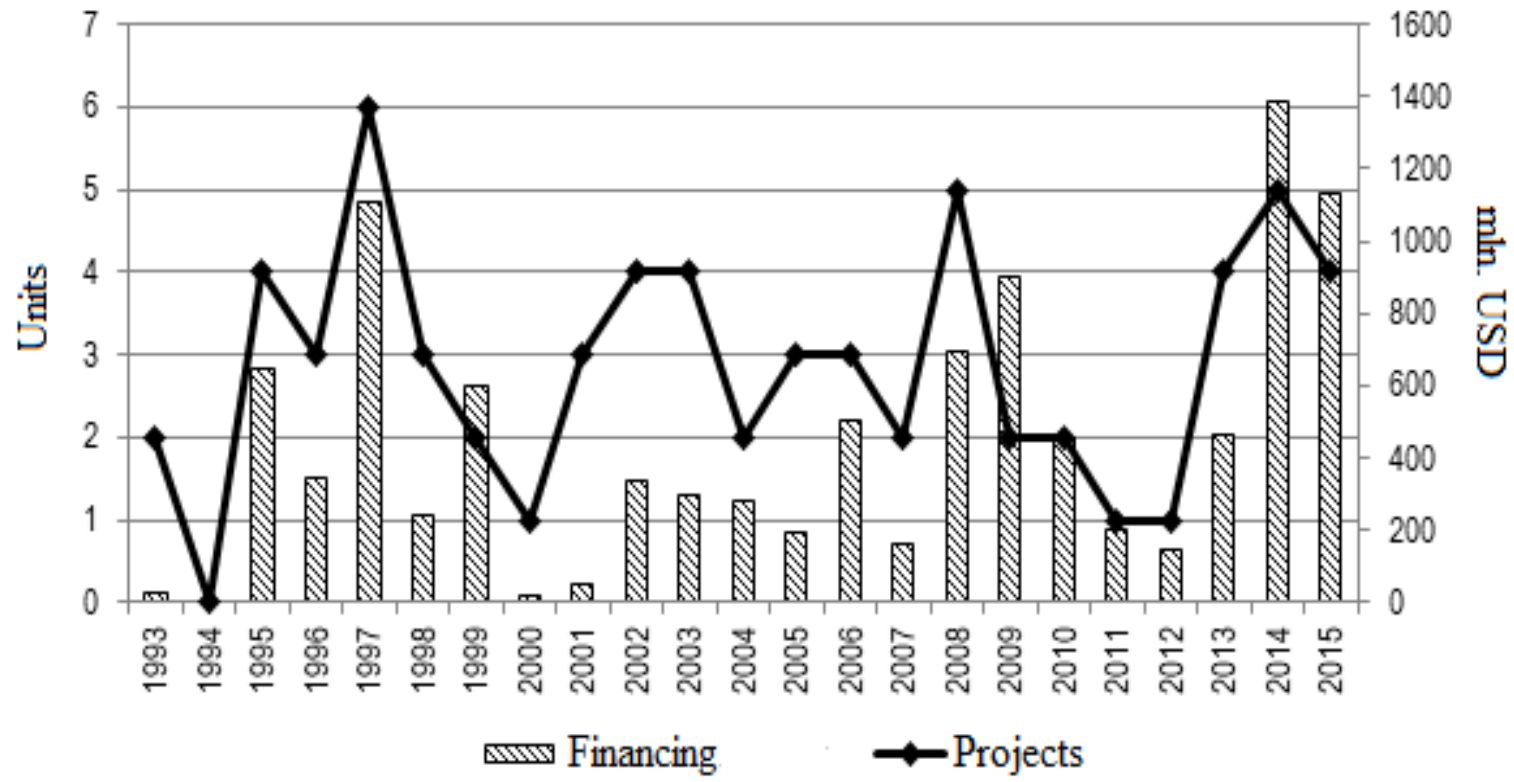

Figure 1. The implementation of World Bank projects in Ukraine for 1993-2015

Source: [11]. 
Among these projects, the thematic areas for environmental projects implementation take a prominent position (see Figure 2 in Appendix) Climate Change (15), Environmental Policy and Environmental Protection (9), Pollution Prevention (8), Biodiversity (5), Governance (4), Rational use of water resources (4) Other issues of environmental management (3).

Thus, according to our calculations, 48 environmental projects of various levels out of 84 for a total amount of 2,428.1 mln USD were implemented with the financial support of the World Bank.

In this context, it should be noted that the World Bank has paid more attention and financial support to projects than the relevant ministries and departments in Ukraine.

\section{Conclusions}

To discover the strengths and possibilities of the production sharing contracts application as the forms of public-private partnership, it should be noted that they are fully disclosed and systematized for the participants in public-private partnership in scientific sources.

Concerning the economic weaknesses of production sharing contracts, we should mention that due to the lack of confirmed data on economically viable shale gas reserves, complex technological and geological conditions, and also given the survey data of more than 200 experts in oil and gas production, there is a situation where the economic efficiency of shale gas production is reached at a price from 560 USD to 650 USD for thousand $\mathrm{m}^{3}$. In the context of low environmental significance of the production sharing contract, the availability of mandatory provision (reserve) for compensation of negative influence and environmental restoration as an economic implementation factor, in our opinion, should be an important condition for its completion.

Thus, based on the results of the study of the role of public-private partnership in implementing environmental projects to consider sustainable development initiatives, it was revealed that the production sharing agreements are an important form of such partnership from the standpoint of environmental and economic consequences and require a balanced approach to assessment and analysis, considering the potential negative impact on air, water, land resources and human health. To to improve the current procedure for strategic environmental and economic evaluation of public-private partnership projects by the Interdepartmental Commission for conclusion and implementation of production sharing agreements, the Ministry of Economic Development and Trade used the PESTLE analysis in the study of political, economic, social, technological, legal and environmental factors of the external environment and SWOT analysis to discover ecological and economic consequences of these projects implementation. Unlike the existing ones, the proposed approaches consider the environmental significance of the project, its environmental and economic consequences and contain the procedure for a financial reserve formation to compensate the environmental damage.

\section{References}

1. 10 nailuchshikh gosudarstvennykh instrumentov po sokrashcheniyu vybrosov parnikovykh gazov v Severnoy Yevrope [10 best state instruments to reduce greenhouse gas emissions in Northern Europe]. Available at [http://www.airclim.org/sites/default/ales/documents/APC31-The-10-best-climatemitigation-measures-in-Northern-Europe.pdf.

2. Annual report of the Joint Implementation Supervisory Committee to the Conference of the Parties serving as the Meeting of the Parties to the Kyoto Protocol (2014). Lima, 1-12 December 2014, 12 p.

3. Bamberger, M. (2012). Impacts of Gas Drilling on Human and Animal Health. Available at http://www.psehealthyenergy.org/data/Bamberger_Oswald_NS22_in_press.pdf

4. Blake, Martin, Wijetilaka, Shehan (26 February 2015). 5 tips to grow your start-up using SWOT analysis. Sydney. Retrieved 10 August 2015.

5. Collins, Rob (2010). A Graphical Method for Exploring the Business Environment (PDF). Retrieved 19 June 2014.

6. Global reach: World Bank Data. Available at http://maps.worldbank.org/ $\mathrm{p} 2 \mathrm{e} / \mathrm{mcmap} / \mathrm{map} . \mathrm{html}$ ?code $=\&$ level=\&indicatorcode=0553\&title=Global\&org=ibrd .

7. Inderst, G. et al. (2012). Defining and Measuring Green Investments: Implications for Institutional Investors, Asset Allocations. OECD Working Papers on Finance, Insurance and Private Pensions. OECD Publishing, No. 24, 55 p. 
8. Introduction to Environmental Management Systems and related Standards. Available at http://www.snh.org.uk/publications/on-line/advisorynotes/46/46.htm.

9. ISO $14000 \quad-\quad$ Environmental Management. Available at http://www.iso.org/iso/home/standards/management-standards/iso14000.htm

10. Lawrence P. Carr, Alfred J. Nanni Jr. (28 July 2009). Delivering Results: Managing What Matters. Springer Science \& Business Media. p. 44. ISBN 978-1-4419-0621-2.

11. The Millennium Development Goals Report 2014: United Nations, New York. Available at http://www.un.org/millenniumgoals/2014\%20MDG\%20report/MDG\%202014\%20English\%20web.pdf.

12. Osita, Christian, Onyebuchi, Idoko, Justina, Nzekwe (31 January 2014). Organization's stability and productivity: the role of SWOT analysis (PDF). International Journal of Innovative and Applied Research, 2(9), 23-32. Retrieved 17 March 2016.

13. PESTLE analysis history and application, CIPD. Retrieved 2009-10-21.

14. Richardson, J. (2017). A Brief Intellectual History of the STEPE Model or Framework (i.e., the Social, Technical, Economic, Political, and Ecological).

15. Schmieder-Ramirez, J. and Mallette, L. (2015). Using the SPELIT Analysis Technique for Organizational Transitions. Chapter 28 of Education Applications and Developments edited by Mafalda Carmo, Science Press, Retrieved 2015-08-21.

16. Stavins, R. N. (2001). Experience with Market-Based Environmental Policy Instruments. Discussion Paper 01-58, $92 \mathrm{p}$.

17. The U.S. oil and gas boom has had a modest economic impact - so far. - Available at http://www.washingtonpost.com/blogs/wonkblog/wp/2013/04/23/the-oil-and-gas-boom-has-had-asurprisingly-small-impact-on-the-u-s-economy.

18. The Use of Economic Instruments in Environmental Policy: Opportunities and Challenges: United Nations Publication (2004). $121 \mathrm{p}$.

19. UNEP Project manual: formulation, approval, monitoring and evaluation. Available at http://www.unep.org/pcmu/project_manual/chapters.asp.

20. Using the market for cost-effective environmental policy: Market-based instruments in Europe / European Environment Agency (EEA). (2006). Copenhagen, 46 p.

21. Hubanova, O. R. (2010). Orhanizatsiyno-ekonomichnyy mekhanizm stymulyuvannya osvoyennya tekhnohenno-resursnoho potentsialu Ukrayiny: avtoref. dys. [Organizational-economic mechanism of stimulation of development of technogenic-resource potential of Ukraine: abstract of a thesis]. Odesa: B.v., $36 \mathrm{p}$.

22. Mishenin, Y. E. et al. (2013). Derzhavno-pryvatne partnerstvo yak instrument formuvannya rynku ekosystemnykh posluh. V Determinanty sotsial'no-ekonomichnoho rozvytku pidpryyemstv: monohrafiya [State-private partnership as a tool for the formation of the market of ecosystem services. In Determinants of socio-economic development of enterprises: a monograph]. Kharkiv: TOV Disa Plyus, pp. 50-64.

23. Netradytsiynyy i neznaydenyy Mif pro velyki zapasy slantsevoho hazu v SSHA [Non-traditional and undiscovered Myth about large shale gas reserves in the US]. Available at http://necu.org.ua/netradytsiynyy-i-neznaydenyy-mif-pro-velyki-zapasy-deshevoho-slantsevoho-hazu-vssha/.

24. Povil'nyi rukh v nikudy: rozvytok slantsevoho hazu v Yevropi [Slow motion to nowhere: the development of shale gas in Europe]. Available at http://necu.org.ua/povilnyy-ruh-v-nikudy-rozvytok-slantsevoho-hazu-vevropi/.

25. United Nations (2008). Practical guidance on effective governance in the public-private partnership. $128 \mathrm{p}$.

26. Pro uhody pro rozpodil produktsiyi: Zakon Ukrayiny vid 14 veresnya 1999 r. Vidomosti Verkhovnoyi Rady Ukrayiny (VVR) [About product-sharing agreements: Law of Ukraine dated September 14, 1999] (1999). Bulletin of the Verkhovna Rada of Ukraine, 44, p. 391.

27. Rassadnikova, S. I. (2012). Priorytetni napryamy derzhavno-pryvatnoho partnerstva u rozbudovi ekolohichnoyi infrastruktury Ekonomichni innovatsiyi [Priority directions of public-private partnership in the development of ecological infrastructure]. Odessa: Ipride National Academy of Sciences of Ukraine. Odesa: IPREED NAN Ukrayiny, 48, pp. 192-203.

28. Slantseva uhoda \#2. Tekst URP z Chevron [Slate Agreement No. 2. The text of the PSA with Chevron] [Electronic resource]. Available at http://www.epravda.com.ua/publications/2013/06/12/379523/]. 
29. Ukrayina na rozryv: Vydobutok netradytsiynoho hazu [Ukraine on the gap: extraction of unconventional gas]. Natsional'nyy ekolohichnyy tsentr Ukrayiny [National Ecological Center of Ukraine], 2014, 42 p.

30. Fakty pro frekinh: Shcho vam treba znaty pro vydobuvannya hazu netradytsiynykh pokladiv [Facts about fracturing: What you need to know about gas extraction of non-traditional deposits] (2014). National Ecological Center of Ukraine, 4 p.

31. Frolov S. M. et al. (2013). Derzhavno-pryvatne partnerstvo yak mekhanizm investuvannya innovatsiynykh tekhnolohiy povodzhennya $\mathrm{z}$ vidkhodamy [Public-private partnership as a mechanism for investing in innovative waste management technologies]. Biznes-inform, 3, 181-185.

\section{Appendix}

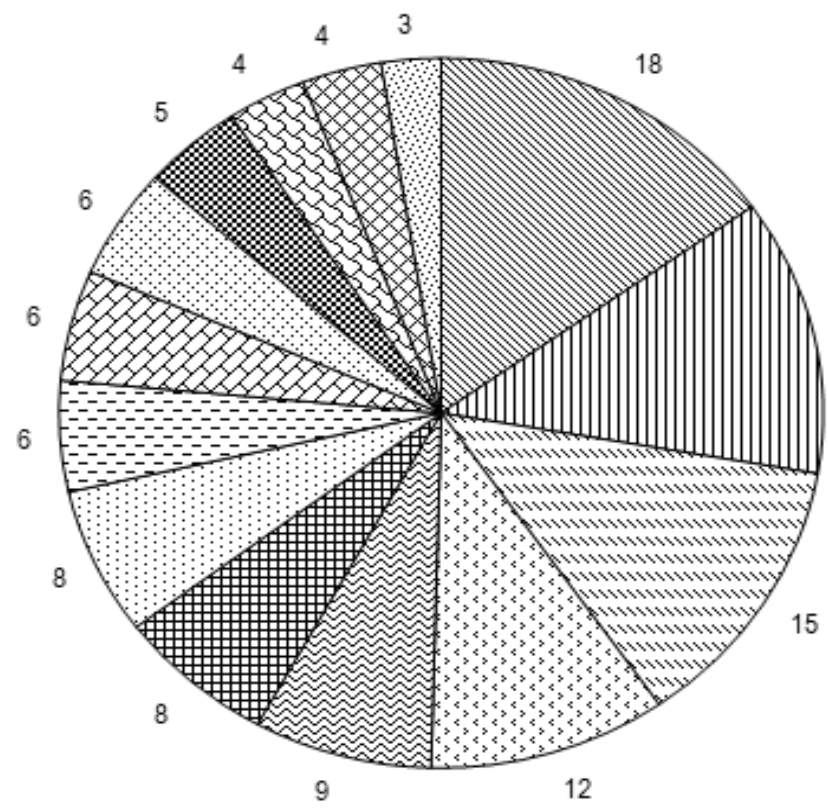

\$ State regulation of competition

mClimate change

๒ Structural adjustment

$\square$ Public expenditure financial sector management and procurement system

( $)$ Environmental policy and conservation measures

It Infrastructure for the private sector

$\square$ Prevention of environmental pollution

口Administrative reform

$\checkmark$ Export development

๑ Internaional financial standards

Biodiversity

$\checkmark$ Land management

$\bowtie$ Rational use of water resources

O. Other issues of environmental management

Figure 2. The structure of environmental projects of various levels in Ukraine, implemented with the support of the World Bank

Source: [6]. 